Outside his business and professional interests his activities included forestry, heraldry and archaeology, and in particular the study of the churches of his native Norfolk. In the course of a life-long enthusiasm hardly a week went by without his paying a visit to one or more churches, and he claimed to have examined nearly every ecclesiastical building in the county. He contributed several valuable papers to the transactions of the Norfolk and Norwich Archaeological Society, of which for some years he was Secretary and later President. For many years he had been a Fellow of the Society of Antiquaries.

He was essentially a religious man, a Past Master of the Union Lodge of Freemasons and played a prominent part in many good causes. He leaves a widow, and a son and daughter.

B. ROBARTS

\title{
JAMES BACON
}

JAMES BACON died on 2 October 1964 in his eighty-fourth year. 'J. B.', as he was affectionately known to his many friends and colleagues, had lived a very full professional life, although he had had to overcome, from time to time, periods of relatively serious ill-health. He died in close contact with his sons and daughters and their children, by whom he is mourned, and to whose welfare he had devoted so much of his life. He lost the companionship of his wife in 1948.

As a young man he spent his leisure walking among the hills of the Lake District, while preparing for the Fellowship of the Institute, which he attained in 1903. An intimate friend remembers his early ambitions: to earn $£ 1,000$ a year, to become a Member of Parliament, and to have a happy family. Ambitions change with the years and, although he stood on onc occasion as a Parliamentary candidate, professional interests overcome political ones but, with this alteration of direction, he reached those objects which he set out to achieve.

James Bacon will be remembered as a consulting actuary but in his early business years he was with the Liverpool Victoria Insurance Corporation, becoming their first Actuary and Secretary and the proud possessor of Life Policy No. 1.

IIl-health brought his resignation in 1912 and he joined the firm of Ackland \& Rea, of which he became the head after Ackland's death in 1916. Included in the portfolio was the National Deposit Friendly Society and James Bacon was responsible for discussions with the Registrar of Friendly Societies regarding the method of valuation to be applied to a deposit society, a method which has justified itself over the years. In 1919 Guy Woodrow became a partner of the firm, then to be known as Bacon \& Woodrow, later to be joined by Francis Bacon, whose subsequent succession to the senior partnership was a matter of great pride to his father.

From the commencement of his career 'J. B.' gave the benefit of his intellect and activity to the Institute and it is surely fitting that, with his illustrious name, it can be truly said that he paid his debt to his profession. His initial contribution to our proceedings came in the year following the completion of his training in a joint paper with T. G. Ackland 'On the Valuation of Whole Life Assurances with allowance for Lapses', to be followed in 1907 by 'A Pension Fund Problem; with some remarks on the deduction of salaryscales'. In 1929 he gave to the members some insight into mortality conditions culled from the consulting practice in 'An Experience of Indian Assured Lives in the State of Mysore'.

James Bacon served with distinction on the Council during the period between 1927 and 1947, being elected Vice-President in 1940 and Treasurer in 1944. One remembers 
with pleasure the occasions when his independence of thought and fearlessness on matters which might be considered controversial assisted in guiding the actions of the Council. He was invaluable to the consultants in the formation of the Association of Consulting Actuaries, of which he became the Joint President and to which he gave of his time and knowledge until he ceased to be able to come regularly to London.

Attendance at Institute meetings was a high priority to 'J. B.' and many were the valuable contributions he made to our discussions. International congresses also benefited greatly from his devotion to his professional life. He was a founder of the Denarius Club, and a regular diner with the Actuaries', Fellowship and Gallio Clubs. During the war his presence and assistance were greatly welcomed by a group of younger members in the establishment of the Woolgatherers and their discussions were illuminated by his views, always enunciated in a concise, yet controversial, manner.

$\mathrm{He}$ became a member of the Insuranto Lodge in 1927, rising to the highest offices in Freemasonry. His contemporary, Frank Makepeace, records "We were all fond of "J. B.", and the Lodge and Chapter are the poorer by his passing'.

After a professional career extending over a period of more than sixty years, James Bacon leaves a memory of a forthright, capable man with great tenacity of purpose, helpful to those who sought his advice and assistance and a very pleasant companion to his friends.

W. H. CLOUGH 